\title{
KARAKTERISASI RIZOBAKTERI YANG BERPOTENSI MENGENDALIKAN BAKTERI XANTHOMONAS ORYZAE PV. ORYZAE DAN MENINGKATKAN PERTUMBUHAN TANAMAN PADI
}

\author{
Agustiansyah $^{1 *}$, Satriyas Ilyas ${ }^{2}$, Sudarsono $^{2}, \&$ Muhammad Machmud $^{3}$ \\ ${ }^{1}$ Jurusan Agroteknologi Fakultas Pertanian Universitas Lampung \\ J1. Prof. Soemantri Brodjonegoro No.1 Bandar Lampung 35145 \\ ${ }^{2}$ Departemen Agronomi dan Hortikultura, Fakultas Pertanian IPB. \\ J1. Meranti, Kampus IPB Dramaga, Bogor 16680. \\ ${ }^{3}$ Balai Besar Penelitian Bioteknologi dan Sumberdaya Genetik Pertanian. \\ Jl. Tentara Pelajar N0.3A, Bogor 16111. \\ *penulis untuk korespondensi E-mail: agustiansyahn@yahoo.com
}

\begin{abstract}
Characterization of rhizobacteri having potential to control Xanthomonas oryzae pv. oryzae and increase plant growth of rice. Rhizobacteria which are isolated from root could produce $\mathrm{HCN}$, siderophore, and plant growth regulator, induce systemic resistance, and are increase uptake of plant nutrition such as phosphate. The objective of this research was to characterize rhizobacteri as controling agent for Xanthomonas oryzae pv.oryzae (Xoo) and as plant growth promoter. The results show that the isolates of P. diminuta A6, P. aeruginosa A54, B. subtilis $11 / \mathrm{C}$, and B. subtilis 5/B inhibited the growth of Xoo. B. subtilis 5/B isolate produced the highest siderophore activity, followed by of $P$. aeruginosa A54, $P$. diminuta A6 and $B$. subtilis $11 / \mathrm{C}$. Only $P$. diminuta A6 isolate produced HCN. The results also showed that all rhizobacteri produced IAA i.e.

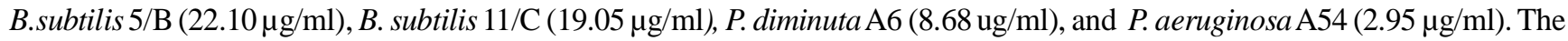
content of phosphatase enzyme was as folows B.subtilis 5/B (2.78 units/ ml), B.subtilis 11/C (5.7 units/ml), P. diminuta A6 (2.25 units $/ \mathrm{ml})$, and $P$. aeruginosa A54 (5.71 units / $\mathrm{ml})$. Content of peroxidase enzymes in plants that were treated by using isolates was as follows B. subtilis $5 / \mathrm{B}\left(1.30 \times 10^{-3} \mathrm{units} / \mathrm{mg}\right.$ protein $)$, P. aeruginosa $\mathrm{A} 6\left(1.20 \times 10^{-3}\right.$ units $/ \mathrm{mg}$ protein $)$, B.subtilis

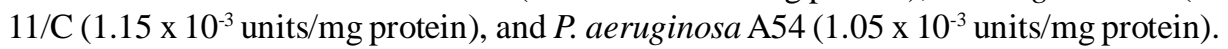

Key words: biological control, bacterial leaf bligth, phytostimulator, plant growth regulator.

\begin{abstract}
ABSTRAK
Karakterisasi rizobakteri yang berpotensi mengendalikan bakteri Xanthomonas oryzae pv. oryzae dan meningkatkan pertumbuhan tanaman padi. Rizobakteri yang diisolasi dari perakaran tanaman dapat memproduksi asam sianida (HCN), siderofor, zat pengatur pertumbuhan tanaman, menginduksi ketahanan sistemik tanaman, dan dapat meningkatkan penyerapan hara fosfat. Penelitian ini bertujuan untuk mengetahui karakter rizobakteri yang mengait dengan kemampuan mengendalikan bakteri Xanthomonas oryzae pv. oryzae (Xoo) penyebab penyakit hawar daun bakteri (HDB) dan kemampuan meningkatkan pertumbuhan tanaman. Hasil pengujian menunjukkan bahwa isolat $P$. diminuta A6, P. aeruginosa A54, B. subtilis 11/C, dan B.subtilis 5/B memiliki kemampuan menghambat pertumbuhan Xoo. Keempat isolat menghasilkan senyawa siderofor dengan aktivitas tertinggi pada isolat $B$. subtilis 5/B diikuti isolat $P$. aeruginosa A54, P. diminuta A6, dan B.subtilis 11/C. Hanya isolat P. diminuta A6 yang memproduksi senyawa HCN. Keempat isolat memproduksi IAA, enzim fosfatase, melarutkan fosfat, dan memiliki kandungan enzim peroksidase. Besarnya kandungan IAA masing-masing isolat adalah B.subtilis 5/B (22,10 $\mu \mathrm{g} /$ $\mathrm{ml})$, B. subtilis $11 / \mathrm{C}(19,05 \mu \mathrm{g} / \mathrm{ml})$, P. diminuta A6 $(8,68 \mu \mathrm{g} / \mathrm{ml})$, dan isolat $P$. aeruginosa A54 $(2,95 \mu \mathrm{g} / \mathrm{ml})$. Kandungan enzim fosfatase masing-masing adalah B.subtilis 5/B (2,78 unit/ml), B.subtilis 11/C ( 5,7 unit/ml), P. diminuta A6( 2,25 unit/ml), dan $P$. aeruginosa A54 (5,71 unit $/ \mathrm{ml})$. Kandungan enzim peroksidase adalah isolat B.subtilis 5/B (1,30 x $10^{-3}$ unit $/ \mathrm{mg}$ protein), $P$.

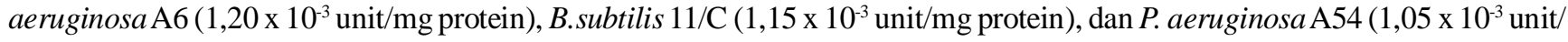
mg protein).
\end{abstract}

Kata kunci: agens hayati, fitostimultor, hawar daun bakteri, zat pengatur tumbuh. 


\section{PENDAHULUAN}

Bakteri akar pemacu pertumbuhan tanaman (plant growth-promoting rhizobacteria, PGPR) saat ini semakin banyak dikembangkan, terutama dalam upaya peningkatan produksi pangan dan perbaikan kualitas lingkungan hidup. Penggunaan PGPR untuk pengurangan input kimia pertanian telah menjadi isu penting. Rizobakteri telah banyak diaplikasikan pada banyak tanaman karena dapat meningkatkan pertumbuhan, daya tumbuh benih di lapang, dan meningkatkan produksi tanaman. Beberapa rizobakteri telah diperdagangkan (Ashrafuzzaman et al., 2009; Herman et al., 2008; Minorsky, 2008).

Mekanisme rizobakteri dalam mengendalikan penyakit maupun populasi patogen melalui beberapa cara yaitu produksi senyawa antibiosis, persaingan ruang atau nutrisi, persaingan pemanfaatan unsur $\mathrm{Fe}$ melalui produksi siderofor, induksi mekanisme ketahanan, inaktivasi faktor perkecambahan patogen, penguraian faktor kepatogenan seperti toksin, parasitisme yang melibatkan produksi enzim ekstrasel pendegradasi dinding sel, misalnya kitinase, $\beta-1.3$ glukanase (Van Loon, 2007). Penyakit Hawar Daun Bakteri (HDB) yang disebabkan oleh bakteri Xanthomonas oryzae $p v$. oryzae (Xoo) dan defisiensi hara fosfor adalah kendala dalam budidaya padi yang menyebabkan rendahnya produktivitas tanaman. Menurut Vikal et al. (2007), HDB dapat menurunkan produksi sampai 50\%. Ji et al. (2008) menyatakan pengurangan hasil berkisar 20-40\%. Penyakit HDB juga merupakan penyakit terbawa benih (Agarwal \& Sinclair, 1996; Veena et al., 1996; Ilyas et al., 2007).

Beberapa karakter penting rizobakteri dalam meningkatkan pertumbuhan tanaman adalah menghasilkan hormon tumbuh seperti IAA (Karnwal, 2009), giberelin (Joo et al., 2005), memfiksasi N (Park et al., 2005; Hafeez et al. 2006), dan melarutkan $\mathrm{P}$ (Faccini et al., 2004; Mehrvraz \& Chaichi, 2008). Khusus pada kemampuan melarutkan $\mathrm{P}$, rizobakteri seperti Pseudomonas spp. dan Bacillus spp. dapat mengeluarkan asam- asam organik seperti asam formiat, asetat, dan laktat yang bersifat dapat melarutkan bentukbentuk fosfat yang sukar larut tersebut sehingga menjadi bentuk yang tersedia bagi tanaman (Rao, 2007).

Dua kelompok bakteri yang dilaporkan dan banyak dikembangkan sebagai agens pengendalian hayati adalah kelompok Bacillus spp. dan Pseudomonas spp. khususnya pada tanaman padi. Gnanamanickam et al. (1999) menyatakan bahwa Bacillus spp. mampu mengendalikan Xoo penyebab HDB pada tanaman padi. Velusamy et al. (2006) melaporkan antibiotika 2.4 diacetylphloroglucinol (DAPG) yang diproduksi $P$. fluorescens mampu menghambat pertumbuhan HDB oleh patogen Xoo. Ilyas et al. (2007), melaporkan agens hayati dari kelompok Bacillus spp. mampu menghambat pertumbuhan koloni Xoo yang berasal dari benih padi yang diuji secara in vitro. Kemampuan agens hayati dalam meningkatkan pertumbuhan dan pengendalian penyakit pada berbagai komoditas telah banyak dilaporkan peneliti, tetapi informasi tentang penggunaan agens hayati dalam meningkatkan pertumbuhan, penyerapan hara fosfat, pengendalian penyakit, dan peningkatan mutu benih padi belum banyak dilaporkan, khususnya di Indonesia.

Penelitian ini bertujuan untuk mengetahui karakter rizobakteri kelompok Pseudomonas spp. dan Bacillus spp. yang mengait dengan kemampuan mengendalikan bakteri Xanthomonas oryzae pv. ryzae penyebab HDB dan meningkatkan pertumbuhan tanaman padi.

\section{METODE PENELITIAN}

Penelitian dilaksanakan di Laboratorium Bakteriologi, Balai Besar Penelitian Bioteknologi dan Sumberdaya Genetik Pertanian Bogor, Laboratorium Mikrobiologi dan Biokimia Pusat Penelitian Bioteknologi IPB, dan Laboratorium Bakteriologi Fakultas Kedokteran Hewan IPB, dari April 2008 sampai Agustus 2009.

Isolasi Bakteri Antagonis dari Akar Padi. Bakteri diisolasi dari rizosfer padi sehat di antara tanaman padi terinfeksi Xoo. Isolasi rizobakteri dilakukan sebagai berikut: (1) sebanyak 10 gram akar padi dengan butiran tanah yang masih melekat di permukaan akar dimasukkan ke dalam labu erlenmeyer berisi $100 \mathrm{ml}$ air akuades steril; (2) labu erlenmeyer berisi sampel dikocok dengan menggunakan shaker dengan kecepatan 150 rpm selama 30 menit; (3) suspensi yang didapat diencerkan secara berseri dari $10^{-1}$ sampai $10^{-10}$ dan setiap tahapan pengenceran dihomogenisasi berulangulang; (4) suspensi yang diperoleh disemaikan dalam medium agar King's B untuk menumbuhkan bakteri dari kelompok Pseudomonas spp. yang berpendar; (5) Biakan kultur bakteri yang diperoleh diinkubasi pada suhu ruangan selama 48 jam; (6) setiap koloni bakteri yang tumbuh diisolasi dan dibuat biakan murninya. Selanjutnya bakteri yang telah dimurnikan dipilih secara cepat untuk melihat kemampuan daya hambat patogen dengan cara menggoreskan bakteri yang diuji di atas media nutrient agar dalam cawan Petri melintasi/ memotong goresan bakteri patogen. Bakteri rizofir yang berpotensi sebagai agens hayati diidentifikasi 
menggunakan prosedur baku menurut Schaad et al. (2001).

\section{Uji Daya Hambat Rizobakteri terhadap} Xanthomonas oryzae pv. oryzae. Uji daya hambat (uji antagonisme) terhadap Xoo secara in vitro dilakukan untuk memilih bakteri rizofir yang berpotensi sebagai agens hayati. Pengujian daya hambat rizobakteri terhadap patogen juga dilakukan pada isolat Bacillus subtilis 5/B dan isolat Bacillus subtilis 11/C yang merupakan koleksi penelitian sebelumnya. Biakan murni Xoo (Patotipe 4, asal BB Penelitian Tanaman Padi, Sukamandi) berumur 48 jam dengan kerapatan 4,5 x $10^{8} \mathrm{sel}$ bakteri $/ \mathrm{ml}$ skala $4 \mathrm{McFarland}$ sebanyak $100 \mu \mathrm{l}$, disebar dalam media peptone sucrose agar (PSA). Potongan kertas saring (diameter $1 \mathrm{~cm}$ ) yang telah direndam dalam larutan yang mengandung agens hayati (dengan kerapatan 4,5 x $10^{8} \mathrm{sel}$ bakteri/ml) berumur 48 jam diletakkan di tengah cawan Petri yang selanjutnya diinkubasi pada suhu kamar selama 5 hari dan setiap hari diamati. Pengamatan dilakukan dengan melihat pembentukan lingkaran zona hambatan (halo) Xoo oleh rizobakteri yang ada pada kertas saring. Masing-masing isolat agens hayati dilakukan pengujian dengan tiga ulangan. Pengamatan dilakukan dengan cara mengukur panjang diameter vertikal dan horizontal zona bening yang terbentuk. Nilai diameter daya hambat yang diperoleh dianalisis ragamnya dan dilanjutkan dengan uji Jarak Berganda Duncan.

Produksi Senyawa HCN. Produksi senyawa HCN kualitatif dianalisis dengan menggunakan metode yang dikembangkan Bekker \& Schipper (Munif 2001). Isolat rizobakteri yang diuji ditumbuhkan pada media glisina dalam cawan petri. Pada bagian tutup cawan petri ditempelkan potongan kertas saring yang telah direndam dalam larutan untuk mendeteksi HCN (asam pikrat $2 \mathrm{~g}$ dan natrium karbonat $8 \mathrm{~g}$, dalam $200 \mathrm{ml}$ air). Biakan kultur bakteri diinkubasi pada suhu ruang. Sebagai petunjuk terbentuknya senyawa $\mathrm{HCN}$ akan terjadinya perubahan warna pada kertas saring. Warna kertas saring yang tetap kuning menunjukkan isolat yang diuji tidak memproduksi HCN sedangkan warna coklat muda, coklat tua dan merah bata menandakan produksi $\mathrm{HCN}$ yang semakin meningkat.

Produksi Siderofor. Produksi siderofor dari isolat rizobakteri yang diuji dilakukan dengan menumbuhkan bakteri dalam media uji selama 24 jam pada suhu ruang. Komposisi per liter media yang digunakan adalah sukrosa $20 \mathrm{~g}$, Lasparagin $2 \mathrm{~g}, \mathrm{~K}_{2} \mathrm{HPO}_{4} 1 \mathrm{~g}$, dan $\mathrm{MgSO}_{4}$ 0,5 g. Suspensi rizobakteri disentrifius dengan kecepatan
$11.000 \mathrm{rpm}$ selama 30 menit. Supernatan disaring dengan membran nitroselulosa $0,2 \mu \mathrm{m}$. Pendeteksian produksi siderofor oleh rizobakteri dilakukan dengan cara menambahkan $1 \mathrm{ml} \mathrm{FeCl} \mathrm{0,01} \mathrm{M}$ ke dalam $3 \mathrm{ml}$ supernatan dan sebagai pembanding supernatant tanpa penambahan $\mathrm{FeCl}$. Deteksi siderofor diukur menggunakan spektrofotometer (model Novaspec II) pada panjang gelomang $410 \mathrm{~nm}$ (Dirmawati 2003).

Kemampuan Melarutkan Fosfat. Dalam pengujian kemampuan rizobakteri untuk melarutkan fosfat digunakan media agar Pikovskaya dengan penambahan tri-calcium phosphate (TCP) sebagai sumber fosfat. Komposisi per liter media yang digunakan terdiri atas glukosa $10 \mathrm{~g}, \mathrm{NaCl} 0,2 \mathrm{~g}, \mathrm{KCl} 0,2 \mathrm{~g}, \mathrm{MgSO}_{4} 0,1 \mathrm{~g}$, $\mathrm{MnSO}_{4}$ 2,5 mg, $\mathrm{FeSO}_{4} 2,5 \mathrm{mg}$, ekstrak khamir 0,5 g, $\left(\mathrm{NH}_{4}\right)_{2} \mathrm{SO}_{4}$ 0,5 g, dan agar $15 \mathrm{~g}$. Media disterilkan dengan pemanasan menggunakan otoklaf dan setelah pH media diatur menjadi 7,2 dengan KOH $5 \mathrm{~N}$. Media dituangkan ke dalam cawan Petri, dibuat lubang dengan pelubang gabus dan diisi dengan $0,5 \mathrm{ml}$ suspensi isolat rizobakteri yang diuji. Media dengan bakteri diinkubasi selama 3 hari pada suhu ruang. Kemampuan melarutkan fosfat dari isolat yang diuji dievaluasi secara kualitatif berdasarkan terbentuknya halo di sekitar lubang yang berisi suspensi rizobakteri (Thakuria et al., 2004).

Pengukuran Aktivitas Enzim Fosfatase. Pengukuran aktivitas enzim fosfatase dilakukan dengan mengikuti metode Heinonen dan Lahti (1981) dan Greiner et al. (1997) yang dikutip oleh (Budiansyah, 2010). Pengukuran didasarkan pada jumlah fosfat anorganik yang dapat dibebaskan dari mioinositol. Larutan sampel dibuat dengan cara, sebanyak $100 \mu \mathrm{l}$ asam fitat $1.0 \mathrm{mM}$ dimasukkan ke dalam tabung mikro, kemudian ke dalamnya ditambahkan larutan penyangga natrium asetat $0,1 \mathrm{M}$ pH 5 sebanyak $250 \mu$ l. Setelah diinkubasi pada suhu $37{ }^{\circ} \mathrm{C}$ selama 10 menit, sebanyak 50 ul sampel enzim dimasukkan ke dalamnya, kemudian diikubasikan kembali selama 30 menit pada suhu $37^{\circ} \mathrm{C}$. Sebanyak $1,5 \mathrm{ml}$ larutan AMM (asam sulfat $5 \mathrm{~N}$, aseton dan larutan ammonium molibdat $10 \mathrm{mM}$ dengan perbandingan 1:1:2) ditambahkan untuk menghentikan reaksi. Selanjutnya ditambahkan 100 ul $1 \mathrm{M}$ asam sitrat sebagai penstabil reaksi enzim fosfatase. Sampel di sentrifius dengan kecepatan 10.000 rpm selama 10 menit. Larutan kontrol dibuat dengan cara yang sama, tetapi penambahan enzim tidak dilakukan sebelum inkubasi selama 30 menit pada suhu $37^{\circ} \mathrm{C}$. Penambahan enzim dilakukan bersamaan dengan penambahan larutan AMM dan asam sitrat, sebelum larutan disentrifius. Sebagai standar $\mathrm{P}$ digunakan $\mathrm{KH}_{2} \mathrm{PO}_{4} 0,1 \mathrm{~g} / 50 \mathrm{ml} \mathrm{H}_{2} \mathrm{O}$. Aktivitas enzim 
fosfatase dibaca absorbansinya dengan spektrofotometer pada panjang gelombang $400 \mathrm{~nm}$ terhadap warna kuning yang terbentuk.

\section{Produksi Asam Indol Asetat (IAA) oleh Isolat} Rizobakteri. Isolat Pseudomonas spp. ditumbuhkan selama 24 jam dalam medium King's B cair, sedangkan Bacillus spp. dalam larutan Nutrient Broth (Schaad et al., 2001). Sintesis auksin dipacu dengan cara menambahkan asam amino triptofan $0,5 \mathrm{~g} / \mathrm{l}$ ke dalam media. Biakan kultur bakteri disentrifugasi dengan kecepatan $10.000 \mathrm{rpm}$ selama 10 menit, kemudian supernatan dipisahkan dari endapan bakteri, disaring dengan membran nitroselulosa berporositas $0,2 \mu \mathrm{m}$, dan dianalisis kandungan IAA-nya. Kandungan IAA dalam filtrat kultur bakteri dideteksi dengan menggunakan pereaksi $\mathrm{FeCl}_{3} 12 \mathrm{~g} / \mathrm{l}$ dalam 7,9 $\mathrm{M} \mathrm{H}_{2} \mathrm{SO}_{4}$. Pereaksi $\mathrm{FeCl}_{3}(1 \mathrm{ml})$ dan filtrat kultur bakteri $(1 \mathrm{ml})$ ditambahkan ke dalam tabung eppendorf (volume $2 \mathrm{ml}$ ), dan campuran diinkubasi dalam ruang gelap pada suhu 25 ${ }^{0} \mathrm{C}$ selama 30 menit. Setelah periode inkubasi, nilai absorban campuran dibaca dengan spektrofotometer (model Novaspec II) pada panjang gelombang $550 \mathrm{~nm}$. Kurva standar berdasarkan nilai absorban larutan IAA murni dengan konsentrasi $0,6,25,12,5,25,5,75,100$, 150, dan $200 \mu \mathrm{g} / \mathrm{ml}$ digunakan untuk menghitung kandungan IAA dalam filtrat kultur bakteri (Glickman \& Dessaux, 1995).

Aktivitas Enzim Peroksidase. Aktifitas peroksidase diukur dengan cara menggerus $1 \mathrm{~g}$ daun bibit padi (umur 21 hari setelah tanam) dalam $0,1 \mathrm{M}$ bufer fosfat $\mathrm{pH} 6,5$ pada suhu $4{ }^{\circ} \mathrm{C}$. Homogenat disaring dengan kain kasa halus dan filtrat disentrifius dengan kecepatan $6.000 \mathrm{rpm}$ pada suhu $4{ }^{\circ} \mathrm{C}$ selama 20 menit. Supernatan disiapkan sebagai sumber enzim pada kuvet sampel spektrofotometer. Sebanyak $1,5 \mathrm{ml}$ dari $0,05 \mathrm{M}$ pyrogallol dan $100 \mu$ l ekstrak enzim dimasukkan ke dalam kuvet. Reaksi dimulai dengan menambahkan $100 \mu 11 \%$ $\mathrm{H}_{2} \mathrm{O}_{2}$ ke dalam kuvet sampel dan diamati setiap 30 detik dengan spektrofotometer pada panjang gelombang 420 nm (Vidhyasekaran et al., 2001).

\section{HASIL DAN PEMBAHASAN}

Uji daya hambat Xoo, Produksi Senyawa HCN, dan Siderofor. Berdasarkan hasil pengujian isolat dalam menghambat pertumbuhan Xoo menunjukkan bahwa keempat isolat yaitu $P$. diminuta A6, isolat $P$. aeruginosa $\mathrm{A} 54$, isolat B. subtilis $11 / \mathrm{C}$, dan isolat B.subtilis 5/B mampu menghambat pertumbuhan Xoo. Hal ini dapat dilihat dari zona bening yang terbentuk disekitar isolat (Tabel 1, Gambar 1). Kemampuan menghambat pertumbuhan patogen ini berkaitan dengan kemampuan agens hayati menghasilkan $\mathrm{HCN}$ dan siderofor.

Hasil pengujian isolat dalam menghasilkan $\mathrm{HCN}$, hanya isolat $P$. diminuta A6 saja yang memproduksi senyawa HCN (Gambar 2). Semua isolat rizobakteri yang diuji menghasilkan senyawa siderofor dan dari pembacaan nilai absorbsi dengan panjang gelombang $550 \mathrm{~nm}$, isolat B.subtilis 5/B menghasilkan aktifitas siderofor tertinggi, diikuti isolat $P$. aeruginosa $\mathrm{A} 54$, isolat P. diminuta A6, dan isolat B.subtilis 11/C (Gambar 3). Menurut Fuente et al. (2004), senyawa HCN merupakan salah satu metabolit sekunder yang dihasilkan oleh bakteri Pseudomonas spp. dan bersifat antimikroba. Sebelumnya Rayder et al. (1994) menyatakan bahwa kemampuan isolat bakteri menghasilkan $\mathrm{HCN}$ ditentukan juga oleh ketersediaan Fe.

Siderofor adalah senyawa pengkelat besi dalam kondisi kekurangan $\mathrm{Fe}$ yang disekresikan oleh mikroorganisme (Dwivedi \& Johri 2003) dan siderofor paling banyak mengandung grup hydroxamate dan catechol yang berfungsi mengkelat $\mathrm{Fe}$ (Siddiqui, 2005). Peningkatan jumlah mikrba penghasil siderofor pada rizosfer tanaman famili Graminae (rerumputan) berhubungan dengan meningkatnya kemampuan penekanan penyakit (Crowley, 2001). Produksi siderofor oleh rizobakteri merupakan salah satu karakter dan

Tabel 1. Hasil identifikasi dan uji nilai tengah zona hambat empat isolat rizobakteri

\begin{tabular}{clc}
\hline Kode isolat & \multicolumn{1}{c}{ Rizobakteri } & Diameter zona hambat $(\mathrm{cm})$ \\
\hline A6 & Pseudomonas diminuta & $2,02 \mathrm{a}$ \\
$11 / \mathrm{C}$ & Bacillus subtilis & $1,22 \mathrm{bc}$ \\
5/B & Bacillus subtilis & $1,08 \mathrm{~cd}$ \\
A54 & Pseudomonas aeruginosa & $1,43 \mathrm{~b}$ \\
\hline
\end{tabular}

Angka-angka yang diikuti oleh huruf yang sama enunjukan tidak berbeda nyata menurut uji Duncan pada $\alpha$ 5\%. 

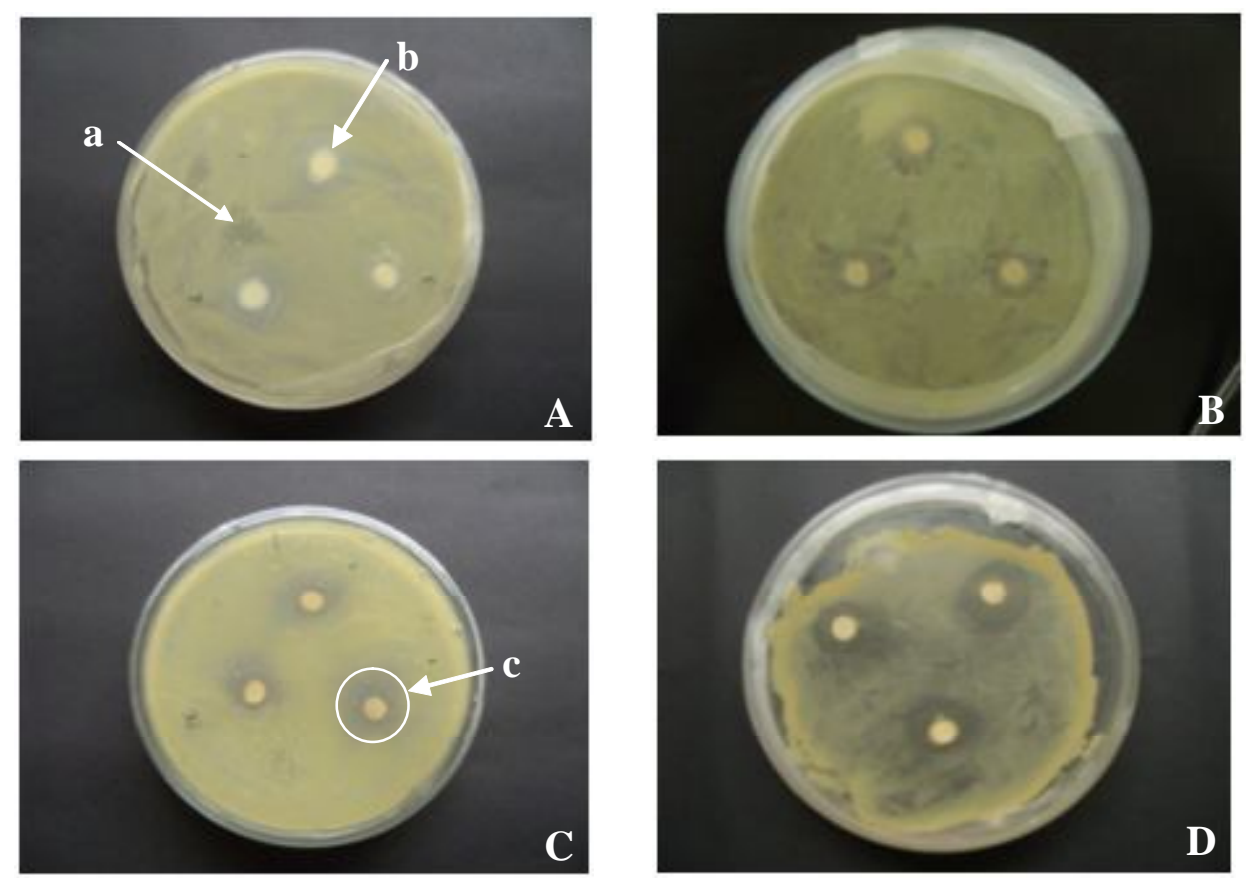

Gambar 1. Hasil uji daya hambat rizobakteri. (A) isolat B.subtilis 11/C, (B) isolat B.subtilis 5/B, (C) isolat $P$. diminuta A6, dan (D) isolat $P$. aeruginosa A54. Tanda panah: (a) bakteri Xoo, (b) kertas saring pembawa rizobakteri, dan (c) zona hambat terhadap pertumbuhan Xoo.
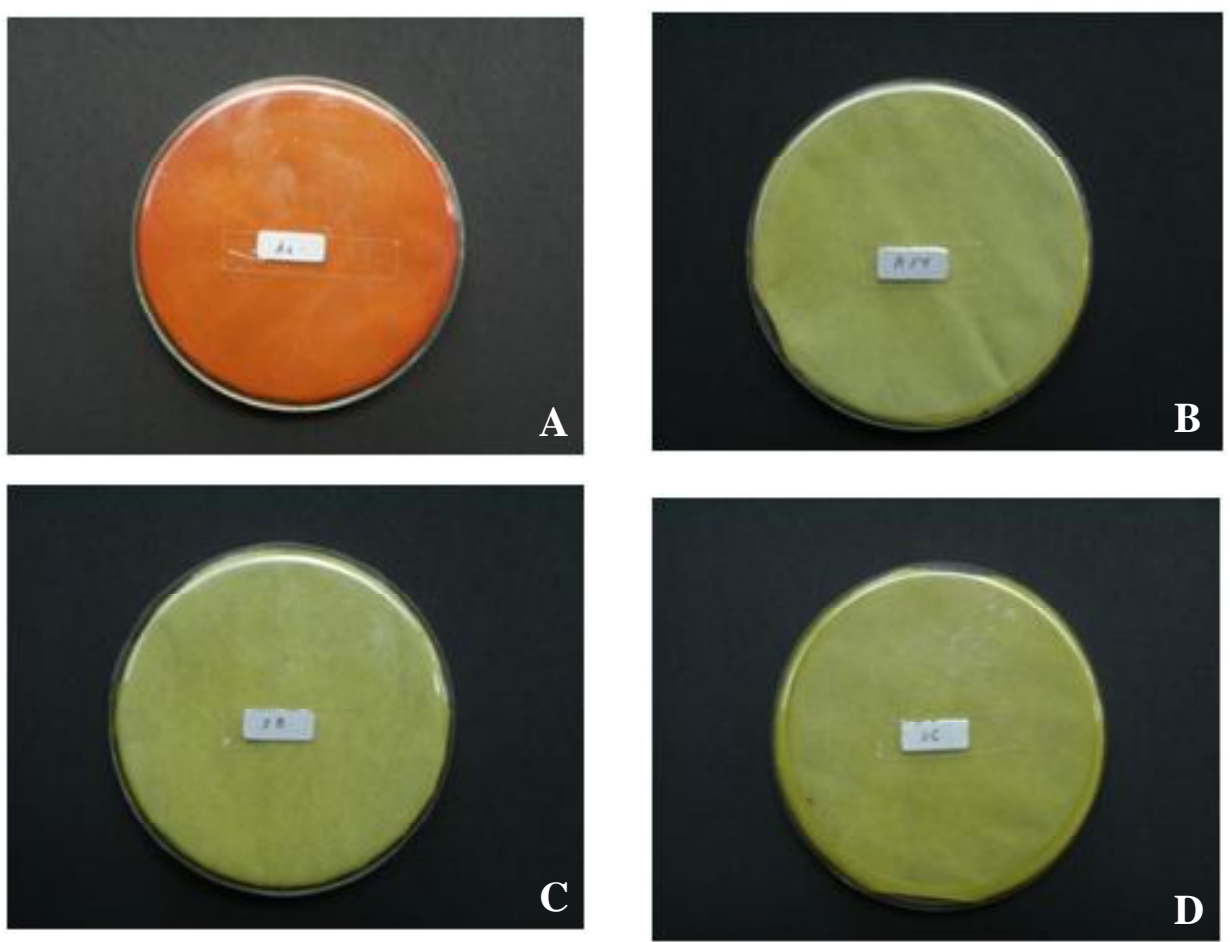

Gambar 2. Produksi HCN oleh isolat $P$. diminuta A6 pada media Glisina. (A) $P$. diminuta A6, (B) $P$. aeruginosa A54, (C) B. subtilis 5/B, dan (D) B.subtilis 11/C. Warna kertas saring merah bata mengindikasikan HCN diproduksi oleh rizobakteri dan kertas saring berwarna kuning mengindikasikan HCN tidak diproduksi oleh rizobakteri. 


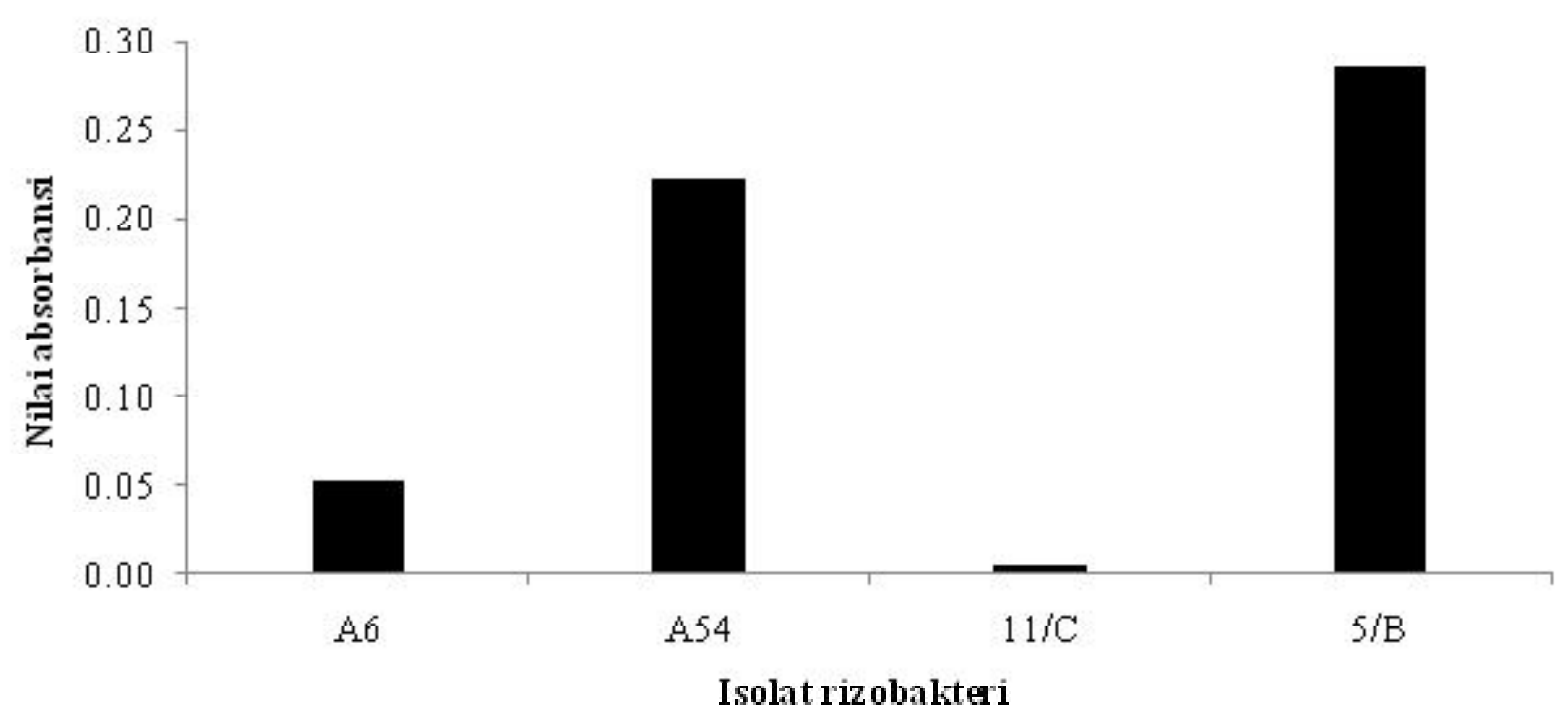

Gambar 3. Kemampuan isolat agen hayati menghasilkam senyawa siderofor. Aktivitas siderofor secara kualitatif ditentukan berdasarkan nilai absorbansi pada panjang gelombang $(\lambda) 550 \mathrm{~nm}$. A6 = P. diminuta; A54 = P. aeruginosa $; 11 / \mathrm{C}=$ B. subtilis; $5 / \mathrm{B}=$ B. subtilis.

mekanisme dalam menekan pertumbuhan patogen. Menurut Kazempour (2004), mekanisme rizobakteri sebagai antagonis patogen dilakukan melalui kompetisi terhadap hara $\mathrm{Fe}$ yang juga digunakan untuk pertumbuhan mikroba lainnya. Mulya et al. (1996) menyatakan bahwa rizobakteri yang menghasilkan siderofor dan antibiotika lebih efektif menekan penyakit dibandingkan dengan rizobakteri yang menghasilkan siderofor atau antibiotik saja.

\section{Kemampuan Melarutkan Fosfat dan Aktifitas} Enzim Fosfatase. Semua isolat rizobakteri yang diuji mampu melarutkan fosfat. Kedua kelompok rizobakteri yaitu Pseudomonas spp. dan Bacillus spp. pada media uji Pikovskaya yang ditambahkan tri-calcium phosphate (TCP) sebagai sumber fosfat menghasilkan halo di sekitar pada media uji. Khan et al. (2009) menyatakan bahwa bakteri Pseudomonas spp. dan Bacillus spp. merupakan bakteri yang efektif dalam memperbaiki ketersediaan fosfat di dalam tanah. Terbentuknya halo tersebut menunjukkan kemampuan rizobakteri melarutkan fosfat. Selain itu, hasil pengujian aktifitas enzim fosfatase menunjukkan adanya aktifitas enzim fosfatase pada rizobakteri yang diuji (Tabel 2; Gambar 4). Menurut Rodriquez et al. (2004), rizobakteri pelarut fosfat dapat merubah fosfat tidak larut dalam tanah menjadi bentuk yang terlarut dan tersedia bagi tanaman. Halder et al. (1990) menjelaskan bahwa kemampuan rizobkateri melarutkan kompleks Kalsium fosfat $(\mathrm{Ca}-\mathrm{P})$ berkaitan dengan kemampuannya mereduksi $\mathrm{pH}$ di sekitarnya dan produksi asam organik atau proton. Asam organik akan secara langsung melarutkan mineral fosfat hasil perubahan anion $\mathrm{PO}_{4}^{2-}$ oleh anion asam atau dengan mengikat ion $\mathrm{Fe}$ dan $\mathrm{Al}$ yang berasosiasi dengan fosfat. Richardson et al. (2011) menjelaskan asam organik yang dihasilkan oleh mikroba tanah melepaskan mineral fosfat yang terikat dengan $\mathrm{Al}, \mathrm{Fe}$, dan $\mathrm{Ca}$.

Produksi Asam Indol Asetat. Hasil percobaan menunjukkan keempat isolat rizobakteri yang diuji memproduksi asam indol asetat (IAA) saat ditumbuhkan dalam media yang ditambahkan dengan asam amino triptofan. Isolat B.subtilis 5/B memproduksi IAA tertinggi yaitu $22.10 \mu \mathrm{g} / \mathrm{ml}$. Produksi IAA terendah dihasilkan oleh isolat $P$. aeruginosa A54 yaitu $2.95 \mu \mathrm{g} /$ $\mathrm{ml}$. Hasil analisis produksi IAA oleh masing-masing rizobakteri disajikan pada Tabel 3. Hasil ini sesuai dengan hasil penelitian terdahulu bahwa isolat Pseudomonas spp. (Khalid et al., 2005; Karnwal, 2009) dan Bacillus spp. (Khalid et al., 2005) mampu menghasilkan IAA. Kemampuan rizobakteri menghasilkan IAA ditentukan oleh jumlah asam amino triptofan yang tersedia diperakaran tanaman yang dapat disintesis oleh rizobakteri. Hal ini disebabkan asam amino triptofan merupakan subtrat utama pembentukan IAA. Menurut Thakuria et al. (2004) dan Karnwal (2009), kemampuan menghasilkan IAA ditentukan oleh jenis rizobakteri yang diuji dan kemampuan mengkolonisasi akar tanaman. Kemampuan rizobakteri mengkolonisasi perakaran tanaman berimplikasi pada jumlah asam amino triptofan yang diperoleh dari eksudat akar 
Tabel 2. Pembentukan halo dan aktivitas enzim fosfatase oleh empat isolat rizobakteri pada medium Pikovskaya.

\begin{tabular}{lcc}
\hline \multicolumn{1}{c}{ Rizobakteri } & Halo & Aktivitas enzim fosfatase (unit $/ \mathrm{ml}$ ) \\
\hline P. diminuta A6 & + & 2,25 \\
P. aeruginosa A54 & + & 5,71 \\
B. subtilis 11/C & + & 1,39 \\
B. subtilis $5 / \mathrm{B}$ & + & 2,78 \\
\hline
\end{tabular}

tanda + berarti terdapat halo dan mampu melarutkan fosfat.
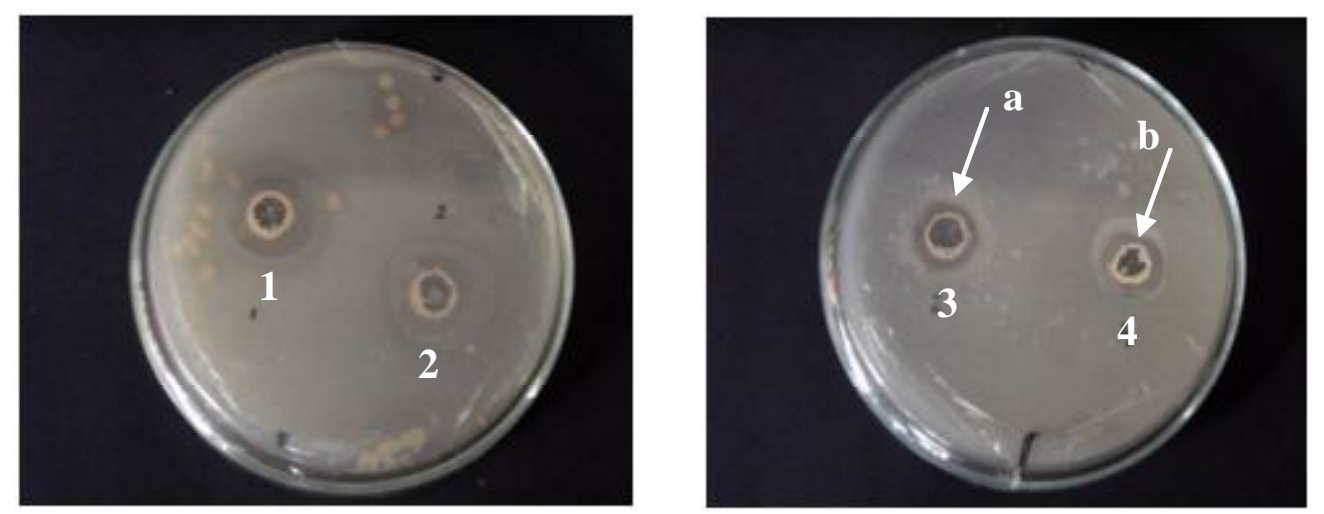

Gambar 4. Kemampuan rizobakteri melarutkan fosfat. (1) P. diminuta A6,(2) P. aeruginosa A54, (3) B. subtilis $11 / C$, dan (4) B. subtilis isolat 5/B. Tanda panah (a) menunjukkan zona bening pelarutan fosfat medium Pikovskaya, (b) sumur tempat rizobakteri ditempatkan.

Tabel 3. Konsentrasi IAA yang dihasilkan empat isolat rizobakteri pada media yang mengandung asam amino triptofan.

\begin{tabular}{lc}
\hline \multicolumn{1}{c}{ Rizobakteri } & Konsentasi IAA $(\mu \mathrm{g} / \mathrm{ml})$ \\
\hline P. diminuta A6 & 8,68 \\
P. aeruginosa A54 & 2,95 \\
B. subtilis 11/C & 19,05 \\
B. subtilis $5 / \mathrm{B}$ & 22,10 \\
\hline
\end{tabular}

tanaman. Produksi IAA oleh rizobakteri hanya akan terjadi jika konsentrasi asam amino triptofan di daerah perakaran tanaman cukup tinggi (Karnval, 2009).

Aktivitas Enzim Peroksidase. Pada Tabel 4 dapat dilihat bahwa tanaman yang diberi perlakuan rizobakteri memiliki aktivitas enzim peroksidase lebih tinggi dibandingkan dengan kontrol negatif kecuali pada perlakuan dengan isolat $B$. subtilis A54. Produksi enzim peroksidase tertinggi didapat pada kontrol positif (tanaman diinokulasi Xoo dan tidak diinokulasi agens hayati), diikuti perlakuan tanaman diinokulasi Xoo dan diinokulasi isolat $B$. subtilis 5/B, dan tanaman diinokulasi Xoo dan diinokulasi isolat $P$. diminuta A6. Keempat jenis agens hayati yang digunakan dalam percobaan ini mampu menginduksi ketahanan tanaman terhadap HDB secara sistemik. Hal ini dapat dilihat dari kandungan enzim peroksidase yang dihasilkan pada tanaman yang diuji. Menurut Van Loon (2007) sejumlah enzim bertalian dengan induksi ketahanan sistemik, seperti peroksidase, phenylalanine ammonia-lyase (PAL), lipoxygenase, $\beta$ 1.3 glucanase, dan chitinase. Enzim-enzim tersebut dikenal dengan kelompok PR-protein (Pathogenesisrelated protein). Menurut Van Loon et al. (1998), akumulasi pembentukan PR-protein merupakan indikator resistensi secara sitemik. Peningkatan enzim peroksidase dan enzim lain yang bersifat antimikroba diatur oleh keberadaan asam jasmonat dan etilen yang keduanya diaktifkan oleh mikroba yang bersifat saprofit seperti rizobakteri. Chen et al. (2000) menjelaskan bahwa salah satu enzim yang berperan dalam meningkatkan resistensi tanaman terhadap serangan 
Tabel 4. Kandungan enzim peroksidase (U/mg protein) pada tanaman padi yang diinokulasi dengan Xoo dan mendapat perlakukan rizobakteri.

\begin{tabular}{lc}
\hline \multicolumn{1}{c}{ Perlakuan benih } & $\begin{array}{c}\text { Aktivitas peroksidase } \\
\text { (unit/mg protein) }\end{array}$ \\
\hline Kontrol negatif & $1,05 \times 10^{-3}$ \\
Kontrol positif & $1,80 \times 10^{-3}$ \\
Diinokulasi Xoo dan diinokulasi isolat $P$. diminuta A6 & $1,20 \times 10^{-3}$ \\
Diinokulasi Xoo dan diinokulasi isolat $P$. aeruginosa A54 & $1,05 \times 10^{-3}$ \\
Diinokulasi Xoo dan diinokulasi isolat $B$. subtilis $11 / \mathrm{C}$ & $1,15 \times 10^{-3}$ \\
Diinokulasi Xoo dan diinokulasi isolat $B$. subtilis 5/B & $1,30 \times 10^{-3}$ \\
\hline
\end{tabular}

patogen adalah peroksidase. Peroksidase berperan sebagai pengakatalisis reaksi akhir dalam pembentukan lignin dan fenol lain yang berhubungan dengan pembentukan pertahanan untuk penguatan dinding sel.

\section{SIMPULAN}

Hasil pengujian menunjukkan bahwa isolat $P$. diminuta A6, P. aeruginosa A54, B.subtilis 11/C, dan B.subtilis 5/B memiliki kemampuan menghambat pertumbuhan Xoo. Keempat isolat menghasilkan senyawa siderofor dengan aktivitas tertinggi pada isolat $B$. subtilis 5/B diikuti isolat $P$. aeruginosa A54, $P$. diminuta A6, dan B.subtilis 11/C. Hanya isolat $P$. diminuta A6 yang memproduksi senyawa HCN. Keempat isolat memproduksi IAA, enzim fosfatase, melarutkan fosfat, dan memiliki kandungan enzim peroksidase. Besarnya kandungan IAA adalah isolat B.subtilis 5/B (22,10 $\mu \mathrm{g} / \mathrm{ml})$, B.subtilis 11/C (19,05 $\mu \mathrm{g} /$ $\mathrm{ml})$, $P$. diminuta A6 $(8,68 \mu \mathrm{g} / \mathrm{ml})$, dan isolat $P$. aeruginosa A54 $(2,95 \mu \mathrm{g} / \mathrm{ml})$. Kandungan enzim fosfatase masing-masing adalah B.subtilis 5/B (2,78 unit $/ \mathrm{ml})$, B.subtilis 11/C ( 5,7 unit/ml), P. diminuta A6 (2,25 unit $/ \mathrm{ml})$, dan P. aeruginosa A54 (5,71 unit/ml). Kandungan enzim peroksidase adalah isolat B.subtilis 5/B (1,30 × $10^{-3}$ unit/mg protein), P. aeruginosa A6 (1,20 × $10^{-3}$ unit/mg protein), B. subtilis $11 / \mathrm{C}\left(1,15 \times 10^{-}\right.$ ${ }^{3}$ unit/mg protein), dan $P$. aeruginosa A54 (1,05 x 10 ${ }^{-3}$ unit/mg protein.

\section{SANWACANA}

Terima kasih disampaikan kepada Badan Litbang Pertanian, Kementerian Pertanian RI dan Direktorat Pendidikan Tinggi, Kementerian Pendidikan dan Kebudayaan RI yang telah mendanai penelitian ini melalui Program KKP3T 2008 dan Program Hibah Bersaing Perguruan Tinggi 2009.

\section{DAFTAR PUSTAKA}

Agarwal VK \& Sinclair JB. 1996. Principles of Seed Pathology. New York: Lewis Publishers.

Ashrafuzzaman M, Hossen FA, Ismail MR, Hoque MA, Islam MZ, Shahidullah SM, \& Meon S. 2009. Efficiency of plant growth-promoting rhizobacteria (PGPR) for the enhancement of rice growth. African J. Biotechnol. 8:1247-1252.

Budiansyah A. 2010. Aplikasi cairan rumen sapi sebagai sumber enzim, asam amino, mineral, dan vitamin pada ransum broiler berbasis pakan lokal. [Tesis]. Bogor: Sekolah Pascasarjana, Institut Pertanian Bogor.

Chen C, Belanger RR, Benhamou N, \& Paulitz TC. 2000. Defense enzymes induced in cucumber roots by treatmet with plant growth-promoting rhizobacteria (PGPR) and Phytium aphanidermatum. Physiol. Mol. Plant. Pathol. 56:13-23.

Crowley D. 2001. Fuction of siderophores in the plant rhizosphere. In: Pinton R, Varanini Z, \& Nannipieri P. (Ed.). The rhizosphere: Biochemistry and organic substances at the soil-plant interface. New York: Marcel Dekker, Inc.

Dirmawati SR. 2003. Kajian komponen pengendalian ramah lingkungan penyakit pustul bakteri kedelai [Disertasi]. Bogor: Sekolah Pascasarjana, Institut Pertanian Bogor.

Dwivedi D \& Johri BN. 2003. Antifungals from fluorescens pseudomonads: biosynthesis and regulation. Curr Sci 85:1693-1703.

Faccini G, Garzon S, Martines M, \& Varela A. 2004. Evaluation of the effects of a dual inoculum of phosphate-solubilizing bacteria and Azotobacter chroococcum, in creolo potato (Papa "Criolla") 
(Solanum phureya) var 'YemadeHuevo'. http: \www.ag.auburn.edu/argentina/ pdfmanuscripts/faccini.pdf . [ 17 Januari 2008].

Fuente DL, Bajsa N, Bagnasco P, Quagliotto L, Thomashow L, \& Arias A. 2004. Antibiotic production by biocontrol Pseudomonas fluorescens isolated from forage legume rhizosphere. http://www.ag.auburn.edu/argentina/ pdfmanuscripts/delafuent.pdf. [1 Februari 2010].

Gnanamanickam SS, Brinda P, Narayanana NN, Vasudevan P, \& Kavita S. 1999. An overview of bacterial bligth diseases of rice and strategic for its management. Curr. Sci. 77 :1435- 1443.

Glickman E \& Dessaux Y. 1995. A critical examination of specificity of the salkowski reagent for indolic compound by phytopathogenic bacteria. Appl. Environ. Microbiol. 61:793-796.

Hafeez FY, Yasmin S, Ariani D, Rahman M, Zafar Y, \& Malik KA. 2006. Plant growth promoting bacteria as biofertilizer. Agron. Sustain. Dev 26:143-150.

Halder AK, Misra AK. Bhattacharyya P, \& Chakrabarty PK. 1990. Solubilization of rock phosphates by Rhizobium and Bradyrhizobium. J. Gen. Appl. Microbiol. 36:81-92.

Herman MAB, Nault BA, \& Smart CD. 2008. Effect of plant growth-promoting rhizobacteria on bell pepper production and green peach aphid infestations in New York. Crop Protec. 27: 9961002.

Ilyas S, Sudarsono US, Nugraha TS, Kadir AM, \& Yukti, YF. 2007. Teknik Peningkatan Kesehatan dan Mutu Benih Padi. Laporan Hasil Penelitian KKP3T. Kerjasama Institut Pertanian Bogor dan Balai Besar Penelitian Padi.

Ji HG, Wei LF, He YQ, Wu YP, \& Bai XH. 2008. Biological of rice bacterial bligth by Lysobacter antibiotic strain 13-1. Biol. Control 45:288-289.

Joo GJ, Kim YM, Kim JT, Rhee IK, Kim JH, \& Lee IJ. 2005. Gibberellins-producing rhizobacteria increase endogenous gibberellins content and promote growth of red peppers. J. Microbiol. 43:510-515.

Karnwal A. 2009. Production of indole acetic acid by fluorescent Pseudomonas in the presence of Ltryptophan and rice root exudates. J. Plant Pathol.91:61-63.
Kazempour MN. 2004. Biological control of Rhizoctonia solani, the causal agent of rice sheath blight by antagonis bacteria in green house and field conditions. J. Plant Pathol. 3:88-96.

Khan AA, Jilani G, Akhtar MS, Naqvi SMS, \& Rasheed M. 2009. Phosphorus so-lubilizing bacteria: occurrence, mechanisms and their role in crop production. J. Agric. Biol. Sci. 1: 48-58.

Khalid A, Tahir S, Arshad M, \& Zahir ZA. 2005. Relative efficiency of rhizobacteria for auxin biosynthesis in rhizosphere and non-rhizosphere soil [abstract]. Aus. J. Soil. Res. 42:921-926. http:/ /www.publish.csrio.au/nid/84/paper/SR4019.htm. [ 5 Februari 2010].

Mehrvraz S \& Chaichi MR. 2008. Effect of phosphate solubilizing microorganisms and phosphorus chemical fertilizer on forage and garin quality of barley. American-Eurasian J.Agric. \& Environ. Sci. 3(6):855-860.

Minorsky PV. 2008. Pyrroloquinoline Quinone: ANew Plant Growth Promotion Factor. Plant Physiol. 146: 323-324.

Mulya K, Watanabe M, Goto M, Takikawa Y, \& Tsuyusumu S. 1996. Suppression of bacterial wilt disease in tomato by root dipping with Pseudomonas fluorescens PfG32: The role of antibiotic substances and siderophore production. Ann. Phytopathol. Soc. Jap. 62:132-140.

Munif A. 2001. Studies on the importance of endophytic bacteria for biogical control of root-knot nematode Meloidogyne incognita on tomato [Dissertation]. Bonn, Germany: Institute for Plant Diseases, University of Bonn.

Park M, Kim C, Yang J, Lee H, Shin W, Kim S, \& Sa T. 2005. Isolation and characterization of diazotrophic growth promoting bacteria from rhizophere of agricultural crop of Korea. Micro. Res. 160:127-133.

Rao NSS. 2007. Mikroorganisme dan Pertumbuhan Tanaman. Jakarta: UI Press.

Rodriguez H, Gonzalez T, Goire I, \& Bahsan Y. 2004. Gluconic acid production and phosphate solubilaztion by the plant growth-promoting bacterium azopirilium spp. Naturewissenschaften 91:552-555. 
Rayder MH, Stephens PM, \& Bowen GD. 1994. Improving plant productivity with rhizophere bacteria. Proc. Third International Workshop on Plant Growth-Promoting Rhizobacteria. Adelaide, South Australia, March 7-11, 1994.

Schaad NW, Jones JB, \& Chun W. 2001. Laboratory Guide for Identification of Plant Pathogenic Bacteria. Minnesota: APS Press.

Siddiqui ZA. 2005. PGPR: Prospective Biocontrol Agents of Plant Pathogens. Netherlands: Springer.

Thakuria D, Talukdar NC, Goswami C, Hazarika S, Boro RC, \& Khan MR. 2004. Characterization and screening of bacteria from rhizosphere in rice grown in acidic soil from Assam. Curr. Sci. 86:978-985.

Van Loon LC. 2007. Plant response to plant growthpromoting rhizobacteria. Eur. J. Plant Pathol 119:243-254.

Van Loon LC, Bakker PAHM, \& Pieterse CMJ. 1998. Systemic resistance induced by rhizophere bacteria. Annu. Rev. Phytopathol. 26:379-407.
Veena MS, Khrisnappa, Shetty HS, Mortensen CN, \& Mathur SB. 1996. Seed borne nature transmission of Xanthomonas oryzae pv. oryzae. Plant Pathogenic Bacteria: 420-429.

Velusamy P, Immanuel JE, Gnanamanickam SS, \& Thomashow L. 2006 Biological control of bacterial blight by plant associated bacteria producing 2,4 diacetylphloroglucinol. Canad. J. Microbiol .52:56-65.

Vidhyasekaran P, Kamala N, Ramanathan A, Rajjappan K, Paranidharma V, Velazhahan R. 2001. Induction of systemic resistance by Pseudomonas fluorescens $\mathrm{Pfl}$ against Xanthomonas oryzae pv. oryzae in rice leaves. Phytoparasitica 29:155-166.

Vikal Y, Das A, Patra B, Goel RK, Sidhu JS, \& Singh K. 2007. Identifiction of news sources of bacterial blight resitence in wild oryza species. Plant Genetic Resources 5:108-112. 